\title{
Os significados de ter o coração transplantado: a experiência dos pacientes
}

\section{Experiencing heart transplantation: the patients' perspective}

Noedir Antonio Groppo STOLF ${ }^{1}$, Maria Lucia Araújo SADALA²

RBCCV 44205-834

\section{Resumo}

Introdução: $O$ transplante cardíaco representa, para pacientes com falência cardíaca, a possibilidade de sobrevivência e melhorias na qualidade de vida. Para tanto, faz-se necessária a conscientização e a participação do paciente no trabalho de acompanhamento da equipe de saúde, póstransplante. $O$ objetivo do estudo foi compreender a experiência do transplante cardíaco, partindo da descrição dos pacientes.

Método: Foram entrevistados 26 pacientes, 20 homens e seis mulheres, entre 13 e 71 anos. As convergências dos depoimentos levaram às verdades gerais, que descrevem a experiência vivida.

Resultados: Os participantes revivem as fases do transplante. Comparam sintomas da falência cardíaca com os progressos que conseguiram após transplante. Alguns se sentem saudáveis. Outros relatam persistência da rejeição e complicações; e surgimento de outras afecções. Porém, todos comemoram a melhoria na qualidade de vida. Cada um traz sua visão particular sobre o vivido, sobre familiares e profissionais que compartilham a experiência. Expressamse sobre suas expectativas de realização, no trabalho e na família.

Conclusões: A contribuição deste estudo descritivo reside em desvelar novas perspectivas para a compreensão das

1 - Prof. Titular do Departamento de Cardiopneumologia da Faculdade de Medicina da Universidade de São Paulo. Diretor da Unidade de Cardiopatias Gerais - Transplante, SP.

2 - Enfermeira, Professor Adjunto da Faculdade de Medicina de Botucatu. Professora da Disciplina Relacionamento Enfermeira-Departamento de Enfermagem, Faculdade de Medicina de Botucatu, SP.

Trabalho realizado no Instituto do Coração - Departamento de Cardiopneumologia Faculdade de Medicina, Universidade de São Paulo, SP.

Endereço para correspondência:

Noedir Stolf. Av. Dr. Enéas de Carvalho Aguiar, 44 - Bloco II - 2 andar - sala 13 - Cerqueira César - São Paulo, SP. CEP: 05403-000.

E-mail:stolf@incor.usp.br necessidades deste paciente, capacitando os profissionais que os acompanham a responder mais efetivamente às suas necessidades individuais.

Descritores: Transplante de coração. Qualidade de vida. Adaptação psicológica.

\section{Abstract}

Objective: For patients with heart failure, heart transplantation represents the possibility of survival and improvement in their quality of life. Thus, the awareness and participation of patients in the follow-up work by the healthcare team after transplantation are important. This study aimed at understanding the experience of heart transplantation based on the description of patients.

Methods:Twenty male and six females patients, whose ages ranged from 13 to 71 years old, were interviewed. The similarities of their accounts illustrated shared feelings which described their experiences.

Results: The patients re-experienced the transplantation phases and compared heart failure symptoms with the improvement achieved after transplantation. Some felt healthy whereas others reported the persistence of rejection 
and complications as well as the onset of other pathologies. However, all of them noted the improvement in their quality of life. Each one brought his own views concerning the experience itself, their relatives and the professionals who participated in their experience. They expressed their expectations regarding work and family achievements.

Conclusion: The contribution from this descriptive study

\section{INTRODUÇÃO}

O freqüente êxito nos transplantes cardíacos, representado pelo aumento de sobrevida e qualidade de vida dos transplantados [1-3], aponta este tipo de terapêutica como primeira opção de tratamento para a falência cardíaca refratária, que, no Brasil, assume proporções epidêmicas [4]. O sucesso do procedimento significa não apenas garantir a sobrevida dos pacientes em fase final da cardiopatia, mas permitir-lhe alcançar bons níveis de capacidade física e qualidade de vida [5-7]. Pesquisas brasileiras sugerem a necessidade de acompanhamento profissional consistente pós-transplante, apoiando e educando o receptor para o autocuidado [8,9].

Estudos sobre a qualidade de vida pós-transplante têm enfocado a qualidade de vida dos pacientes antes e após o transplante cardíaco (TC), mostrando melhora dos sintomas e excelente performance física, embora mostrem piora da condição financeira e emocional, em alguns períodos [57,10-12]. Entre estes estudos predomina a abordagem quantitativa, poucos utilizam abordagem qualitativa. Como exemplo de estudo qualitativo, Kaba et al. [13] entrevistaram 42 receptores de coração, investigando as reações e os comportamentos de adaptação às mudanças após o TC, utilizando uma abordagem descritiva e interpretativa; e Kaba [14] entrevistou 11 receptores de coração americanos, procurando descrever os problemas enfrentados em relação a medicações e conflitos psicológicos e sociais. Não foram encontrados estudos fenomenológicos explorando a experiência subjetiva de receptores cardíacos; nesta abordagem há o relevante estudo de Wise [15] sobre receptores de transplante hepático: foram entrevistadas nove crianças entre 7 e 15 anos, com mais de 1 ano de transplante, revelando a percepção destas crianças sobre a experiência vivida e trazendo importantes resultados para subsidiar a sua assistência. Consideramos que pesquisas qualitativas sobre percepção do paciente, a respeito do que lhe acontece no processo de transplante, poderão oferecer subsídios importantes para que se conheçam as suas necessidades, a partir da sua visão própria. Neste sentido, o objetivo deste estudo foi investigar a experiência do TC vivenciada por pacientes transplantados, buscando compreender os significados que eles atribuem a mesma. lies in unveiling new perspectives of understanding such patients' needs, thus helping professionals who assist them to respond more effectively to their individuals necessities.

Descriptors: Heart transplantation. Quality of life. Adaptation, psychological.

\section{MÉTODO}

O estudo foi conduzido na abordagem fenomenológica. O propósito da fenomenologia é o estudo das experiências humanas, a partir da percepção das pessoas que a vivenciam. Partindo das descrições dos receptores de coração sobre como viveram o TC, os pesquisadores buscaram analisar e compreender os significados que eles atribuem à sua experiência, de modo a desvelar os significados convergentes e variações empíricas subjacentes desta experiência [16].

Foram entrevistadas 26 pessoas submetidas a transplante cardíaco (Tabela 1), no período de março de 2003 a março de 2004, agendadas após consultas de rotina. Devido à inexistência de pesquisas enfocando a experiência subjetiva dos receptores de coração, neste estudo selecionamos participantes com as mais diversas características (sexo, idade, tempo de TC, procedência, ocupação), buscando as perspectivas mais diversas dos participantes, para alcançar maior abrangência na compreensão do fenômeno. Não há, nos objetivos dos pesquisadores, pretensão de analisar estas variáveis, que são objetos de estudo de pesquisas quantitativas.

Os participantes foram entrevistados individualmente, colocando-se uma única questão: "Como se mostra para você a experiência de ter o coração transplantado?”, conforme exemplificado na Figura 1. As descrições destes pacientes sobre a experiência vivida foram analisadas mediante os procedimentos fenomenológicos, seguindo os passos propostos por Sadala \& Adorno [16]:

1. Análise individual dos depoimentos (Análise Ideográfica), seguindo as etapas: a leitura atenta do depoimento, procurando apreendê-lo como um todo; a seleção das partes do depoimento que respondem à questão do estudo, chamadas unidades de significado; a análise e compreensão destas unidades de significado, transformando-as na linguagem dos pesquisadores e no enfoque do fenômeno investigado; a interpretação do depoimento como um todo, na compreensão dos pesquisadores (Tabela 2).

2. Busca das convergências de todos os depoimentos (Análise Nomotética): As convergências, tematizadas e analisadas na perspectiva dos pesquisadores, permitiram 
alcançar as verdades gerais sobre o fenômeno estudado, na perspectiva dos participantes do estudo.

O estudo foi aprovado pelo Comitê de Ética em
Pesquisa da Instituição onde se desenvolveu. Os participantes assinaram o Termo de Consentimento Livre e Esclarecido.

Tabela 1. Descrição dos participantes do estudo, São Paulo, 2004.

\begin{tabular}{|c|c|c|c|c|c|}
\hline Participantes & Idade & Sexo & Procedência & Ocupação & Ano do TC \\
\hline 1 & 43 & Masc. & São Paulo & Comerciante & 1994 \\
\hline $\mathrm{P} 2$ & 41 & Masc. & Cotia & Aposentado & 1996 \\
\hline P3 & 60 & Masc. & Diadema & Garçom & 1990 \\
\hline P4 & 49 & Masc. & São Bernardo & Projetista & 1992 \\
\hline P5 & 55 & Masc. & São Paulo & Aposentado & 1998 \\
\hline P6 & 42 & Fem. & Taboão da Serra & Dona de casa & 1994 \\
\hline P7 & 44 & Fem. & São Paulo & Dona de casa & 2000 \\
\hline P8 & 35 & Masc. & São Paulo & Motorista & 2001 \\
\hline P9 & 38 & Fem. & São Paulo & Comerciante & 1999 \\
\hline P10 & 44 & Masc. & Guarulhos & Aposentado & 2003 \\
\hline P11 & 55 & Masc. & São Paulo & Comerciante & 1999 \\
\hline P12 & 32 & Masc. & São Paulo & Aposentado & 1999 \\
\hline P13 & 65 & Masc. & São Paulo & Ferramenteiro & 1990 \\
\hline P14 & 57 & Masc & São Paulo & Aposentado & 1990 \\
\hline P15 & 57 & Masc. & São Paulo & Empresário & 2000 \\
\hline P16 & 71 & Masc. & São Paulo & Aposentado & 1998 \\
\hline P17 & 32 & Fem. & São Bernardo & Estudante & 2002 \\
\hline P18 & 69 & Masc. & São Paulo & Aposentado & 2001 \\
\hline P19 & 50 & Masc. & Limeira & Aposentado & 1992 \\
\hline P20 & 48 & Masc. & São Paulo & Aposentado & 1998 \\
\hline P21 & 17 & Fem. & Piracicaba & Estudante & 1994 \\
\hline P22 & 17 & Fem. & Bebedouro & Estudante & 1994 \\
\hline P23 & 13 & Masc. & Mogi das Cruzes & Estudante & 2000 \\
\hline $\mathrm{P} 24$ & 17 & Masc. & São Paulo & Estudante & 2002 \\
\hline P26 & 37 & Masc. & Ibaté & Comerciário & 2000 \\
\hline
\end{tabular}

TC - Transplante do coração.

"Olhe, eu antes do transplante eu realmente sofri muito. Fiquei uns 4 anos com problema respiratório, sabe. Sofri mesmo. 4 anos terríveis. Falta de ar, ia dormir, não conseguia dormir... foi terrível viu? Os 4 anos sofri muito. Depois que eu fiz o transplante minha vida mudou completamente. Respiro normal, me sinto bem, e faço tudo normal. Tudo o que eu faço no dia a li eu faço normal, uma pessoa com, e faço tudo normal. Tudo que eu faço no dia a día eu faço normal, uma pessoa comum. Não tem nada de novide bem, bem mesmo. O que eu posso dizer é isso á́. (Pausa).Minha vida não mudou nada... Só.... mudou, mudou pra melhor, é claro, estava sofrendo muito. Agora.... agor não, agora eu estou bem, já pra 4 anos, vivo como uma pessoa normal, faço de tudo e como de tudo (reforça o tom da voz), apesar que tem muita coisa que não posso comer mas eu como. Muita coisa que eu não posso comer mas eu como. $\mathrm{E}$ graças a Deus tudo bem.

(Como ele parou perguntei novamente o que significaram para ele esses acontecimentos).

Mudou, mudou pra melhor, é claro, tudo mudou. Agora eu tô bem, faço tudo normal, tudo normal, minha vida é normal. Não mudou nada, só pra melhor. Porque antes eu não podia fazer nada. Não podia caminhar, não podia dormir, não podia fazer nada .. 4 anos que sofri muito. Depois do transplante graças a Deus sou hoje uma pessoa normal. Não sinto mais cansaço... mais nada... A maior parte das pessoas transplantada

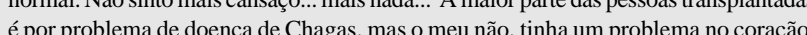

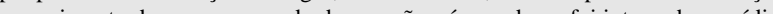

Fig. 1 - A descrição. Depoimento do participante 11, respondendo à questão: "Como se mostra para você a experiência de ter o coração transplantado?" falou que não havia mais outra solução, a não ser transplante. Aí graças a Deus consegui um coração e hoje estou bem. Eu me sinto bem. Minha vida está ótima. (Risos). Melhor impossível. Eu só posso agradecer o que aconteceu comigo porque na época jamais, jamais eu pensaria em viver com o órgão de uma outra pessoa, né. Eu nem acreditava nisso, só acredito porque aconteceu comigo, eu estou vivendo com (Havia da (Havia parado de falar e desliguei o gravador. Adiante ele voltou a falar do transplante
espontaneamente e pedi licença para gravar novamente).

u, na época que eu fiz o transplante, eu estava com 51 anos. E eu recebi o coração de um jovem de 18 anos. Quer dizer, claro... fiquei novo.(Risos). Olhe, geralmente toda a pessoa que faz uma cirurgia dessas tem uma pequena rejeição sempre tem, né. Mas no meu caso não tive rejeição nenhuma! Coisa fantástica! nunca vi um negócio desses. A pessoa... tiraram o coração do rapaz e colocou no meu e não deu defeito nenhum... nenhum, nenhum... olha! Coisa impressionante, nem acredito. Todo mundo goza assim... puxa! Agora você, um senhor de 51 anos está com 18 anos! (Risos)... hoje eu tô com 22, né? na verdade, quando chegar a viver mais 50 anos... eu já passei de cento e tantos anos!(Risos). E outra, geralmente dizem que as pessoas que são transplantadas nunca tá bem de vida, mas eu tô muito bem de vida, muito bem...só posso me queixar da vida, né (Risos). Pois é, como eu falei pra senhora, eu ñ. ño tenho novidade nenhuma, é isso aí. tenho vantagens... me sinto bem demais. Quer dizer, eu faço de tudo, então eu não 
Tabela 2. Análise ideográfica: análise individual do depoimento do paciente 11.

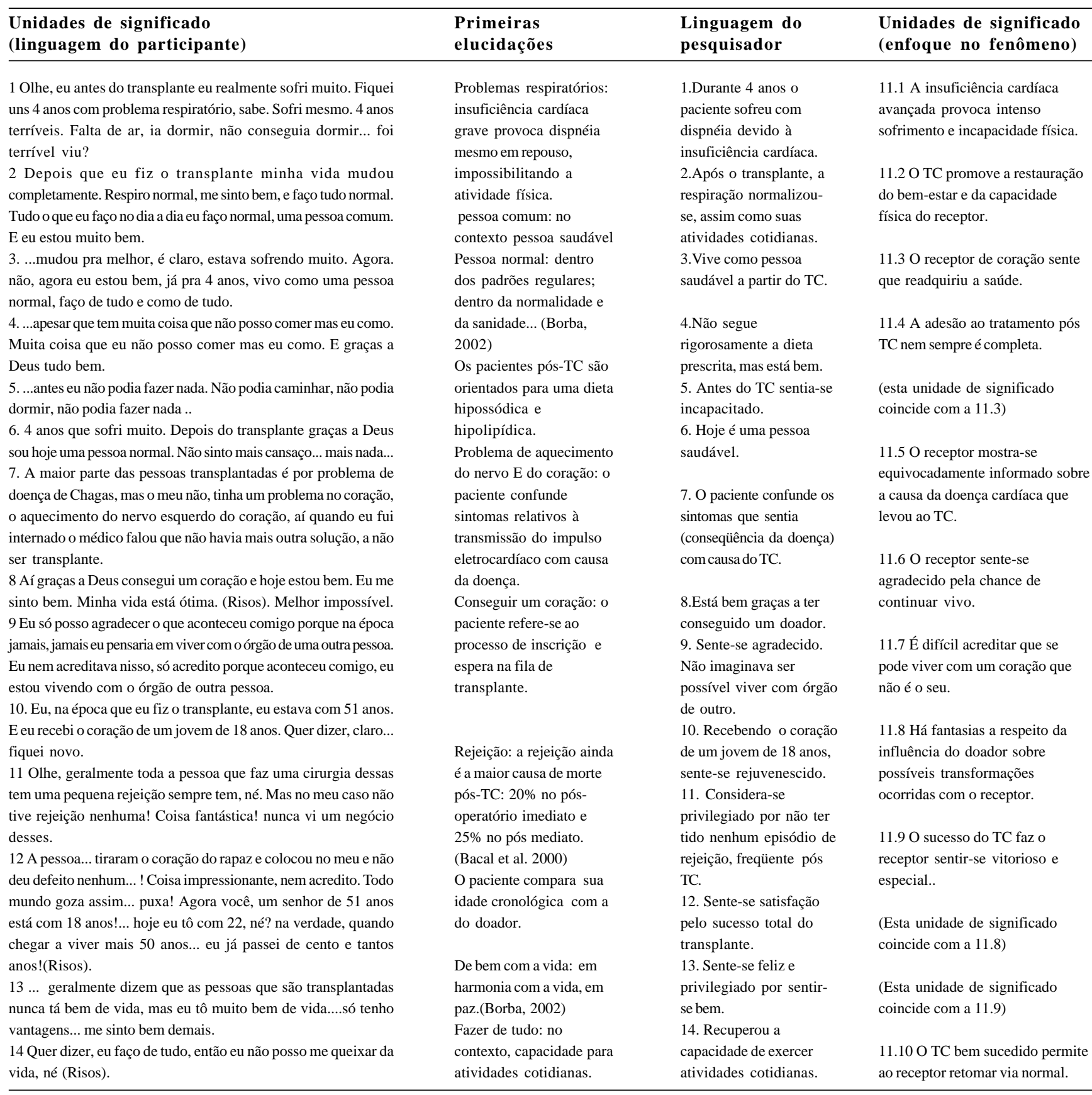

TC - Transplante do coração

\section{RESULTADOS}

As convergências dos depoimentos foram agrupadas em três categorias abertas, que descrevem o fenômeno "a experiência de ter o transplante cardíaco”: o transplante cardíaco, relacionamentos interpessoais e a reflexão sobre a experiência de ter o coração transplantado (Tabela 3).

\section{O Transplante cardíaco}

Deparando-se com o inevitável

Todos participantes encontravam-se no estágio final da insuficiência cardíaca quando lhes foi proposto o transplante como solução. Para alguns significou o fim da incerteza e uma esperança; para outros, sentimentos de insegurança e medo. Todos conscientes de que não seria 
Tabela 3. Categorias que emergiram das entrevistas com 26 receptores de coração respondendo à questão: "Como se mostra para você a experiência de ter o coração transplantado?"

\begin{tabular}{|c|c|c|}
\hline \multicolumn{3}{|c|}{ A reflexão sobre a experiência } \\
\hline O processo do TC & Relacionamentos Interpessoais & de ter o coração transplantado \\
\hline Por que o TC & O doador & Avaliando o significado do TC \\
\hline Sintomas da cardiopatia & Os profissionais & Avaliando as transformações \\
\hline A necessidade do TC & A família & O trabalho \\
\hline Decisão de transplantar & Os companheiros & A consciência sobre si mesmo \\
\hline A espera do TC & A religião & \\
\hline A cirurgia & & \\
\hline A vida pós-TC & & \\
\hline
\end{tabular}

uma escolha, mas a única possibilidade de viver: "O médico falou: 'Você tem filhos? Quer criar seus filhos? É a última chance que você tem, o transplante.' Pensei bem e concordei." (P 7)

Aceitando-se o transplante, há uma longa espera, doadores não compatíveis, intercorrências que obrigam a sair da fila. Conta uma receptora: "Em janeiro, tive de sair da fila porque eu tive uns probleminhas. Em fevereiro, voltei à fila. Quando você começa esse processo de entrar e sair da fila assim... é muita coisa, parece que a doença vai... é como se você, poxa! Você tem a chance de fazer o transplante, mas ao mesmo tempo, será que vai dar tempo? Será que não vai dar tempo? A fila é muito grande, a espera é grande, tudo isso deixa a gente apreensiva.” (P 9)

Para muitos, a história do transplante é a história de uma vitória: bons resultados que se seguiram a períodos difíceis, alcançando-se plena recuperação e voltando à normalidade. Outros descrevem período pós-cirúrgico complicado, com períodos de rejeição, infecção, reinternações e novas cirurgias: "Fui pra casa, dois meses depois me senti mal. Fizeram exames e constataram que eu necessitava de uma cirurgia do pulmão, tinha um abscesso. Foi tirado um terço do pulmão. Melhorei, estava pra ter alta outra vez e tive infecção hospitalar. Fiquei mais quase 50 dias, ao todo oito meses. Depois comecei a me sentir muito bem.” (P 16)

Após o transplante, a vida se transforma. Passa-se a respirar, comer, beber água, movimentar-se, trabalhar. Porém, há as restrições, difíceis de manter: "Quando dá vontade de comer um prato... um exemplo, feijoada, vou lá, pego um pouco, como um pouquinho. Não é que aquilo vai me fazer mal. Não acho que aquilo vai me fazer mal. Lógico, faria mal se toda semana entrar numa feijoada." (P 1)

Convive-se com outros problemas de saúde, com rejeição e adaptação às medicações:

"Depois de quatro anos tive que fazer uma ponte safena e mamária. Acho que a medicação, colesterol, triglicérides alto, então eu tive que fazer uma ponte safena e mamária. Em 99, uma angioplastia. Eu acho... como se diz, eu tô fazendo hora extra (risos).” (P 1)

"Essa rejeição, somada à reação de toxicidade pela ciclosporina, provocou lesão renal e passei a fazer hemodiálise, durante um ano. Aí já comecei a ficar bom, me inscrevi na lista de espera para transplante renal." (P 20)

Apesar das complicações e das limitações, a vida pode ser normal:

"Hoje faço tudo. Trabalho normal na minha casa, busco menino no colégio, vou deitar meia-noite, meia-noite e meia. Meu marido trabalha até tarde, chega tarde em casa...” (P 7)

“Depois não senti mais nada. A gente também sente... doença normal, uma gripe, uma febre, estresse, mas isso é normal pra todo mundo, não é ?’ (P 13)

\section{Relacionamentos interpessoais}

Relacionamentos são desenvolvidos com as pessoas que compartilham a experiência do TC. O doador é lembrado como figura central: “A partir do momento que você tem doador, que você topa fazer o transplante, você começa a enxergar uma luz lá no fundo. A sua vida começa a mudar.” (P 11) Alguns participantes expressam o desejo de agradecer à família doadora. Além da gratidão, há os sentimentos ambíguos:

"Antes de operar a gente fica assim ... meio sentimento de culpa, não sei. Teve um dia que eu perguntei ao $d r Y$ : 'Fico pensando que, pra gente sobreviver, tem uma pessoa que morrer. É uma coisa meio estranha que a gente sente'. Ele falou: 'Não, você não tem que pensar nisso. Você tem que pensar que eu posso atravessar a rua aqui, hoje, e morrer. Eu sou doador. Então, se morrer, o que eu puder doar pra uma pessoa, eu vou doar. Então, acidentes sempre acontecem. Você não pode pensar desta maneira. Você 
tem que ser um pouco egoísta. Pensar em você, porque você depende disso pra sobreviver'. Então deu uma acalmada lá.” (P 2)

Médicos e enfermeiras fazem parte desta experiência. Além da dependência, há por eles sentimentos de gratidão e de afetividade:

"Acho que estou devendo um agradecimento para os médicos, pra toda a equipe que cuidou de mim, eles foram muito bons. $O$ dr. Z., que fez a cirurgia, os médicos que me acompanharam até hoje. Sinto que sou bem tratado aqui, sabe? Isso pra mim é muito importante. Aqui é como se fosse uma extensão da minha casa.” (P 5)

"Em relação ao tratamento e ao hospital, os médicos, é tudo maravilhoso, as enfermeiras... Nem todas mães atendem a gente como as enfermeiras desse hospital, que as mães abandonam a gente, e elas acolhem a gente tão bem.” (P 12)

Os familiares são co-protagonistas da história. O cônjuge está presente, incentiva, ajuda a compreender o que acontece. Os filhos representam o estímulo para lutar.

Encontram-se pessoas estranhas, na mesma situação. Recebe-se o apoio delas e retribui-se o apoio recebido:

"Quando eu estava no leito, o dr. Y pediu para alguns pacientes falarem comigo pelo fato de eu estar super tranqüilo, ter ocorrido tudo bem. Pessoas que estão esperando o transplante estão com medo...estão assim apavorados. Conversei com elas, procurando transmitir serenidade, calma, tranqüilidade e...para não estar tenso, nervoso. Quando se tem um problema, ficar nervoso é pior.” (P 15)

Desenvolve-se a consciência sobre a necessidade de educar as pessoas em relação ao TC: receptores relatam participação em campanhas para estimular a doação de órgãos. Um deles apresenta sua visão crítica:

"Era bom as pessoas despertarem a consciência, com essas campanhas de doação de órgãos. Eu dei depoimento no Incor. Engraçado que no nosso país precisa um famoso aparecer na televisão, ser transplantado, que é pro povo ficar sabendo que é um negócio tão necessário o transplante de órgãos. Parece que é coisa do momento, depois aquieta tudo de novo.”(P 26)

Quando não há perspectivas, recorre-se à fé. Deus, para alguns, seria o responsável por todos acontecimentos:

"Deus permitiu que eu continuasse vivendo, me colocou na mão do dr X, para fazer o transplante. Eu estava desenganado. Minha família, a igreja que freqüento, tudo entrou em orações só com essa finalidade. Não tinha nenhum doador... e apareceu o doador. O doador já veio, parece que foi uma encomenda, porque ele veio com o mesmo peso que eu, mesma altura, mesma caixa torácica...o peso, sangue...o dele era igual o meu." (P 14)
A reflexão sobre a experiência de ter o coração transplantado

Os participantes, ao analisarem o que significou a experiência do TC para a sua existência, expressam-se a respeito da troca de coração, das transformações que sofreram como pessoas e da consciência sobre si mesmos e sobre a realidade atual.

O transplante de coração significou, para todos, nova chance de vida - um renascer. Um participante descreve: "Quando acorda daquela cirurgia, é como se você percebesse que está nascendo de novo. É como se estivesse livre de todos aqueles problemas, você vai começar a engatinhar tudo de novo. Foi assim que eu me senti.” (P 9)

Recupera-se a autonomia e transforma-se o modo de perceber-se:

"Eu me sentia mal de não poder fazer o que queria fazer. Hoje me sinto muito bem, fazendo o que queria e não podia. Graças a Deus. Cuidar dos meus filhos... Antes eu não ia à reunião de pais e filhos....” (P 7)

Recupera-se a perspectiva para o futuro e a continuidade da vida:

"O bom foi que eu voltei a estudar, que antes eu não podia, eu não agüentava ficar na sala de aula. Agora, não, eu vou, volto normal. $O$ ano que perdi eu consegui recuperar na $6^{a}$ série, eu fiz a $6^{a}$ e a $7^{a}$ junto.” (P 21)

Redescobre-se o significado autêntico da vida:

"Você, nossa! Passa a viver novamente. Você entendeu? Você não vegeta mais, você vive. Cada momento, cada dia que você acorda, você agradece a Deus por estar vivo. E cada noite que deita pra dormir, você agradece a Deus por mais um dia." (P 1)

A maioria dos receptores considera que recuperou a saúde, agora são pessoas normais:

"Hoje eu dirijo, eu trabalho, eu faço tudo, eu ando sozinho, eu como de tudo, eu me sinto muito bem. Faz quase 5 anos e estou assim como eu estivesse antes de ter cardiopatia, $100 \%$ de saúde.” (P 16)

"E depois disso não deu mais rejeição. Minha vida, eu não sei... foi melhorando cada vez mais, agora tenho muita saúde, sou uma pessoa normal.” (P 22)

A possibilidade de voltar ao trabalho significa retomar o seu lugar: “Muita gente na época falou: 'Você pode aposentar porque você transplantou'. Mas eu não quis, continuei trabalhando. Trabalho até hoje.” (P 4) Alguns deparam-se com a discriminação: "A pessoa com saúde já é difícil arrumar trabalho. Doente ... quero dizer transplantado é mais complicado.” (P 12)

Alguns receptores falam sobre a troca de coração:

"Em relação ao coração, pra mim é como se não tivesse feito o transplante. Eu digo isso pelo seguinte: não sinto nada, pra mim é o meu que tá aqui, tá entendendo?” (P 1)

“Tiraram o coração do rapaz e colocou no meu. Não 
deu defeito nenhum... nenhum. Coisa impressionante! nem acredito. Todo mundo goza assim:'Puxa! Agora você, um senhor de 51 anos está com 18 anos!' (Ri) Hoje eu tô com 22, né? Quando chegar a viver mais 50 anos, já passei de cento e tantos anos! " (P 11)

Um receptor, após 4 anos, ainda se ressente da perda do seu órgão: "Sempre vai ter aquilo na cabeça da gente, que eu vivo hoje em dia... não vivo mais com meu coração, no caso. Nunca mais será a mesma coisa.” (P 8)

Recém-transplantado, um paciente fala de seus conflitos e ansiedades:

"Eu pensava, mas esse coração, e agora eu vou pra tão longe, é uma especialidade tão individual hoje em dia, poucos locais de assistência. E eu vou pro interior, $4000 \mathrm{~km}$. Ficava pensando: 'E agora?' Tava bem feliz, alegre, um contentamento que também não tem palavras. Enfim, foi muito bom. E esses pensamentos têm repetido assim mais... mais espaçados. Esses pensamentos se repetiam com muita constância. Hoje eu já penso nisso mais vagamente, raramente. Já estou conformado que fui de fato um privilegiado. Hoje já penso nisso muito mais raramente.” (P 25)

Outros relatam como lidam com a ansiedade, procurando superá-la:

"Eu acho que a pessoa quando tá naquela, a pessoa tem mais é que esquecer que vai fazer um transplante, sabe... Vai, lá, faz o transplante, que ela nem vai perceber que foi feito o transplante nela." (P 1)

"Depois da cirurgia, que eu voltei ao normal, senti o coração bater assim. Falei pro médico: 'Tem um negócio esquisito assim', porque antes eu não sentia. Então o coração tava forte, batendo. Ele falou: 'Não, deixa pra lá.' Aí que fui acostumando, novamente. Sabendo que as coisas 'tavam' voltando ao normal.” (P 3)

"Como falei, levo a vida, eu não faço muita questão de lembrar. Acho que as coisas ruins da vida a gente tem que esquecer. Embora foi duro, principalmente naquele pósoperatório, que a gente chega até a balançar algumas vezes, por que passei um sufoco danado mesmo, sabe?” (P 26)

Uma adolescente, transplantada aos oito anos, valoriza o que considerava perdido:

"Estou vivendo a infância que eu perdi, nove anos perdidos. Cresci, desenvolvi. Eu não tinha altura, tinha 1,20 m. Então, pra mim, foi um passo pra eu poder viver. $O$ mais importante foi isso.” (P 21)

\section{DISCUSSÃO}

Os achados do estudo mostram-se consistentes com pesquisas anteriores: a respeito da efetividade do transplante na superação dos sintomas da doença cardíaca em estágio final [2,3,9,11]; e a respeito da rejeição e episódios de infecção, que ainda constituem a maior causa de morbidade e mortalidade nos períodos imediato e mediato pós-operação [17]. Resultados de levantamentos de pacientes operados no Brasil mostram sobrevida de 5 anos para 50\% de pacientes transplantados, $10 \%$ abaixo de índices americanos correspondentes [18,19].

Em relação à qualidade de vida dos receptores, nossos dados assemelham-se aos encontrados na literatura nacional e internacional: ocorrem melhoras em relação aos sintomas físicos e recupera-se o bem-estar geral, embora condicionado a fatores psicossociais e econômicos $[2,3,5,8,9]$; retomam-se as atividades normais e a possibilidade de planejar o futuro, que antes era inacessível. Porém, há insatisfação quanto à vida social e à situação financeira; e oscilações na condição emocional, em alguns períodos [5,9,12,20,21]. Kuhn et al. [20] consideraram que o "distress" está presente em todos os estágios do processo de transplante cardíaco. Dobbels et al. [22] analisaram a persistência de sintomas depressivos e dificuldades dos pacientes em superar dificuldades, cinco a dez anos pós-TC. Uma das preocupações expressa por vários participantes do presente estudo refere-se às dificuldades em voltar ao trabalho, que são mencionadas em estudos de Paris \& White-Williams [5] e Kaba [14] como um dos graves problemas sociais enfrentados pelos receptores de coração.

A dificuldade de aceitar a troca do órgão, expressa por alguns participantes, é comentada por Kaba et al. [13] e Inspector et al. [22], ao analisarem o conflito do receptor diante da perda do próprio coração, com toda a simbologia que este órgão carrega; e a aceitação do coração do doador, que apenas lhe foi destinado em virtude da sua morte. Inspector et al. [22] e Triffaux et al. [23] concluíram que pessoas submetidas ao TC apresentam pensamento mágico e fantasias a respeito órgão, devido ao significado simbólico do coração e ao estresse que perdura por todo o processo pós-TC. Segundo Triffaux et al. [23], as transformações ocorridas neste processo, como um todo, levariam o receptor a perceber a precariedade da existência humana, simultaneamente fazendo brotar a satisfação por nova chance de viver, valorizando-se especialmente os relacionamentos afetivos. Kaba et al. [13] identificaram os modos de "coping" de pacientes para lidar com o estresse pós-TC: desde otimismo exagerado à negação da gravidade do ocorrido; e algumas formas positivas para adequar-se à realidade, recorrendo a apoio externo.

Os dados do presente estudo são similares aos achados das pesquisas mencionadas: os participantes revelam-se satisfeitos e valorizam os resultados do TC, mesmo aqueles que ainda apresentam rejeição e outras complicações. A este respeito, Dew \& Switzer [24] analisaram que esta satisfação, a despeito de dificuldades enfrentadas, deva-se à concepção de que receberam um presente valioso: uma extensão da 
vida, que estavam perdendo. Contrariamente a esta percepção dos participantes do presente estudo, Evangelista et al. [12] equipararam as melhorias da qualidade de vida alcançadas após o TC àquelas obtidas após outros procedimentos (implante de marca-passo, ou a estabilização, por medicamentos, dos sintomas da falência cardíaca), concluindo que a qualidade de vida pós-TC seria inferior à das pessoas saudáveis.

Como é próprio da natureza qualitativa e compreensiva da abordagem fenomenológica, os dados deste estudo desvelam os significados existenciais da experiência de “viver o TC” não mostrados por estudos quantitativos mencionados neste artigo:

- Habitando o universo da doença cardíaca em fase final, os participantes se viram na contingência de terem sido lançados à fatalidade do TC. A única saída para seu sofrimento físico extremo e para a angústia da morte iminente. Esta realidade vivida que, para muitos, está distante no tempo, ainda está viva e presente em todos os depoimentos. Como que ainda influindo no seu modo de viver a realidade presente;

- Após a troca de coração, persistem os sentimentos de sofrimento e insegurança, gerando constante ansiedade: após a cirurgia complexa, a terapia imunossupressora e seus efeitos nocivos; a necessidade de seguir rigorosamente a dieta e as mudanças no estilo de vida, a dependência, para sempre, em relação ao hospital e à equipe de saúde. A luta jamais cessará;

- Tendo consciência desta dependência extrema e dos riscos ainda existentes; enfrentando as mudanças, talvez novas intervenções, talvez novos transplantes; mesmo assim predominam os sentimentos de alegria, todos festejam estar vivos. E aprendem a identificar o essencial na existência.

Estes resultados revelam como é complexa e contraditória a trajetória percorrida. Muitas vezes mostra-se ambígua: esperar pelo transplante significa sofrimento e incerteza, mas é um privilégio encontrar um doador, embora sentindo culpa pela sua morte; ter o coração transplantado significa viver e recuperar a autonomia física, mas também significa a dependência de um tratamento que se prolongará para sempre, e ainda mais sofrimento, e ainda mais luta pela vida. O futuro é incerto. Porém, há o futuro.

A ambigüidade desta realidade mostra-se claramente quando os receptores falam a respeito de terem saúde e levarem vida normal como as "pessoas normais". Mesmo aqueles que continuam com graves complicações póstransplante: dois entre eles correm o risco de um transplante renal devido a estas complicações. Corbin [25] analisa que, na visão das pessoas em geral, ter saúde significa a ausência de sensações estranhas, dor ou desconforto; ao superar os sintomas da doença, o corpo, que se tornara "não familiar" na doença, volta a ser familiar. Assim, as pessoas sentem-se curadas ao readquiriram o controle sobre a sua vida e sobre o seu corpo, voltando às atividades usuais, mesmo quando continuam submetidas a tratamentos para doenças crônicas. Estas concepções sobre a saúde nos remetem ao significado existencial do corpo, no sentido que Merleau Ponty [16] descreve: eu sou o meu corpo, ele é o meu ancoradouro no mundo. É através dele que vivo, atuo, faço minhas trocas com o mundo ao redor. Neste sentido, é possível entender que os participantes, ao falarem que readquiriram a saúde e a normalidade da vida com a troca do coração, falam de como voltaram a agir, a interagir, a aparecer, a viver como o faziam costumeiramente, antes da doença cardíaca. Estudo de Wise [15], sobre crianças e adolescentes pós-transplante hepático, mostra que a principal preocupação destes jovens é ser igual aos seus colegas: eles batalham para se sentirem e serem vistos como "normais"; o que seria inalcançável antes do transplante. Os depoimentos dos quatro adolescentes, participantes do presente estudo, mostram a mesma percepção de ser "saudável” e "normal', que lhes foi possibilitado pelo TC.

Os resultados encontrados sugerem que, em todas as fases do TC, o papel dos profissionais junto ao receptor é crucial, tanto como apoio para a superação das suas ansiedades e inseguranças, como para as ações educativas a respeito das intervenções e orientações durante todo o processo. O sentimento de otimismo, que predomina entre os participantes, provavelmente favorecerá a adesão a estas orientações. Ou talvez signifique uma barreira a esta adesão, se o receptor não tiver consciência sobre suas reais condições e limitações. Neste sentido, a expressão do receptor sobre a sua experiência subjetiva surge como um dado essencial, que deverá ser a base para o seu plano de cuidado.

Outro resultado essencial diz respeito aos familiares dos receptores. Percebidos pelos participantes como o motivo para continuar a luta e como parceiros em todo o processo, sua importância como apoio dos pacientes tem sido reconhecida pelos profissionais de saúde [5,8]. Porém, nem sempre eles são incluídos no processo educativo destinado aos receptores e nem sempre são contemplados com intervenções de apoio, no que se refere à ansiedade e ao sofrimento que enfrentam ao acompanhar o seu familiar. Um participante do estudo solicita, textualmente, que este apoio, tão efetivo para ele, se estendesse aos seus familiares.

Neste sentido, um importante desafio que se coloca para os profissionais, que atuam junto ao receptor, será ajudar indivíduos submetidos ao TC e suas famílias a adaptarem-se à nova situação, a se conscientizarem da sua real condição e possibilidades, a responsabilizarem-se pelo autocuidado: exercendo, com todo o apoio da equipe, ao máximo, a sua autonomia. 


\section{CONSIDERAÇÕES FINAIS}

Este estudo não se propôs a generalizações, mas a descrever o fenômeno estudado, na visão dos participantes, contextualizado no espaço e tempo onde se desenvolveu. Os achados fizeram emergir novas questões a serem investigadas: a adesão ao tratamento pós-TC; relacionamento com doador e família do doador; a família do receptor e seu papel no processo de TC; o trabalho e a adaptação às transformações após o TC; a atuação de enfermeiros e médicos, e outros profissionais da equipe, no apoio aos receptores.

Consideramos que este estudo qualitativo mostra a possibilidade de aproximação ao universo particular de cada paciente, permitindo individualizar a apreensão das suas dificuldades e necessidades. Melhor compreensão da forma como os receptores vivem este processo, nas suas possibilidades e limitações, é essencial para o desenvolvimento de intervenções assegurando que todos alcancem plenamente os benefícios, no contexto do transplante cardíaco e sua evolução contínua.

\section{REFERÊNCIAS}

1. Stolf, NAG, Fiorelli AI, Bacal F, Camargo LF, Bocchi EA, Freitas A et al. Mediastinitis after cardiac transplantation. Arq Bras Cardiol. 2000;74(5):425-30.

2. Grady KL, Jalowiek A, White-Williams C. Predictors of quality of life in patients at one year after heart transplantation. J Heart Lung Transplant. 1999;18(3):202-10.

3. Grady KL, Naftel DC, White-Williams C, Bellg AJ, Young JB, Pelegrin D et al. Predictors of quality of life at 5 to 6 years after heart transplantation. J Heart Lung Transplant. 2005;24(9):1431-9.

4. Ministério da Saúde - Brasil. Óbitos por residência segundo a causa para todo o território brasileiro. Brasília:Ministério da Saúde;1997.

5. Paris W, White-Williams C. Social adaptation after cardiothoracic transplantation: a review of the literature. J Cardiovasc Nurs. 2005;20(Suppl 5):S67-73.

6. de Vitto Dabbs A, Dew MA, Stilley CS, Manzetti J, Zullo T, McCurry KR et al. Psychosocial vulnerability, physical symptoms and physical impairment after lung and heartlung transplantation. J Heart Lung Transplant. 2003;22(11):1268-75.
7. Salmon P, Mikhail G, Stanford SC; Zielinsk S, Pepper JR. Psychological adjustment after cardiac transplantation. J Psychosom Res. 1998;45(5):449-58.

8. Ferraz A, Arakaki H. Atividade física e qualidade de vida após transplante cardíaco. Rev Soc Cardiol Estado de São Paulo. 1995;5(6 supl A):670-8.

9. Amato MS, Amato Neto V, Uip DE. Avaliação de qualidade de vida de pacientes com doença de Chagas submetidos a transplante de coração. Rev Soc Bras Med Trop. 1997;30(2):159-60.

10. Dew MA, Simmons RG, Roth LH Schulberg HC, Thompson $\mathrm{ME}$, Armitage JM et al. Psychosocial predictors of vulnerability to distress in the year following heart transplantation. Psychol Med. 1994; 24(4):929-45.

11. Bunzel B, Laederach-Hofmann K. Long-term effects of heart transplantation: the gap between physical performance and emotional well-being. Scand J Rehabil Med. 1999;31(4):214-22.

12. Evangelista LS, Dracup K, Moser DK, Westlake C, Erickson $\mathrm{V}$, Hamilton MA et al. Two-year follow-up of quality of life in patients referred for heart transplant. Heart Lung. 2005;34(3):187-93.

13. Kaba E, Thompson DR, Burnard P. Coping after transplantation: a descriptive study of heart transplant recipients' methods of coping. J Adv Nurs. 2000;32(4):930-6.

14. Kaba E. The life after heart transplantation for American recipients. Icu Nurs Web J. 2001. Disponível em: http:// www.nursing.gr/Heart pdf

15. Wise BV. In their own words: the lived experience of pediatric liver transplantation. Qual Health Res. 2002;12(1):74-90.

16. Sadala MLA, Adorno RC. Phenomenology as a method to investigate the experience lived: a perspective from Husserl and Merleau Ponty thought. J Adv Nur. 2002;37(3):282-93.

17. Bacal F, Cordeiro VC, Fiorelli AI, Bellotti G, Bocchi EA, Stolf NAG et al. Treatment of persistent rejection with methotrexate in stable patients submitted to heart transplantation. Arq Bras Cardiol. 2000;74(2):145-8.

18. Stolf NAG, Fiorelli AI. Transplante cardíaco. SOCESP: Cardiologia. Rio de Janeiro:Atheneu;1996. p.743-55.

19. Couto WJ, Branco JNR, Dirceu A. Cardiac transplantation and infection. Rev Bras Cir Cardiovasc. 2001;16(2):141-51.

20. Kuhn WF, Brennan AF, Lacefield PK, Brohm J, Skelton VD, Gray LA. Psychiatric distress during stages of heart transplant protocol. J Heart Transplant. 1990;9(1):25-9. 
21. Dobbels F, Geest S, Martin S, Van Cleemput J, Droogne W, Vanhaecke J. Prevalence and correlates of depression symptoms at 10 years after heart transplantation: continuous attention required. Transplant Int. 2004;17(8):424-31.

22. Inspector Y, Kutz I, David D. Another person’s heart: magical and rational thinking in the psychological adaptation to heart transplantation. Isr J Psychiatry Relat Sci. 2004;41(3):161-73.

23. Triffaux JM, Wauthy J, Bertrand J, Limet R, Albert A, Ansseau M. Psychological evolution and assessment in patients undergoing orthotopic heart transplantation. Eur Psychiatry. 2001;16(3):180-5

24. Dew MA, Switzer GE, Goycoolea JM, Allen AS, DiMartin A, Kormos RL et al. Does transplantation produce quality of life benefits? A quantitative analysis of the literature. Transplantation. 1997;64(1):1261-73.

25. Corbin JM. The body in health and illness. Qual Health Res. 2003;13(2):256-67.

\section{COMENTÁRIO}

"Quando o senhor opta pelo método fenomenológico, como desvelamento e intersubjetividade, penso que o conceito do mesmo poderia tornar-se mais abrangente, provavelmente usando a concepção de Heidegger, para torná-lo mais claro. Sabemos que esse filósofo, que aprendeu com Husserl, vê na fenomenologia uma forma de desvelar o que estava oculto, sem que este se mostre concretamente. "O que se manifesta, manifesta aquilo que não se manifesta" (Heidegger) revela exatamente a síntese entre a essência (que se mantém oculta) e a existência (que se manifesta concretamente, como expressão do fenômeno)

Por não se tratar de um método investigatório de natureza científica, pelo menos no que se refere ao conceito de objetividade em pesquisas, torna-se necessário o entendimento daquilo que é o desvelar da essência, sem que a mesma se torne diretamente acessível ao nosso sensório mas, nem por isso, menos verdadeira: como no caso da febre (fenômeno, que se manifesta) denunciando a infecção (essência, que se mantém oculta).

Atenciosamente,

\section{Prof. Dr. Wilson Daher}

Médico psiquiatra. Prof. História da Medicina na Faculdade de Medicina de São José do Rio Preto (FAMERP) 